\title{
Influence of Curriculum and Demographic Factors on Somali Students' Civic Outcomes
}

\author{
Abdinasir Hersi Jama \\ Kulliyyah of Education, \\ International Islamic University Malaysia, \\ Kuala Lumpur, Malaysia \\ abdinasir.shakile@gmail.com \\ Suhailah Hussien \\ Kulliyyah of Education, \\ International Islamic University Malaysia, \\ Kuala Lumpur, Malaysia \\ suhailah@iium.edu.my
}

\author{
Dawood A. Y. Al-Hidabi \\ Kulliyyah of Education, \\ International Islamic University Malaysia, \\ Kuala Lumpur, Malaysia \\ dawood@iium.edu.my \\ Mohamed Ridhuan Abdullah \\ Kulliyyah of Education, \\ International Islamic University Malaysia, \\ Kuala Lumpur, Malaysia \\ ridhuanabdullah@iium.edu.my
}

\begin{abstract}
Somalia is one of the most fiercely divided countries in the world. The people of Somalia face an identity crisis as they have more than one identity (i.e., clan, national, and religious). In addition to this, the development of good Somali citizens is impeded by the absence of a nation to belong to, as there are clan-based states, a lack of clarity as to whether the nation serves the needs of individuals or clans, and an absence of a feeling of obligation towards the nation. These various issues have led to an imperative need to explore how education as a whole and the curriculum, specifically, can build good Somali citizens with a sense of national identity and a participative attitude. Therefore, the current study investigated whether curriculum can be a panacea for the above-mentioned issues. A total of 400 Somali students in their final year of secondary education participated in this study in a cross-sectional survey. The data were analysed using multiple regression analysis. The study found that formal curriculum is a statistically significant contributor to civic development, and is potentially influential in building good citizenship and a national identity in students, hence paving the way for their progressive civic participation in the future. In addition, non-formal curriculum significantly influenced two out of three civic outcomes, i.e., national identity and civic participation. Male and female Somali students differed in their notions of national identity and good citizenship, but demonstrated the same level of or tendency for civic participation. Interestingly, parental education did not exercise any significant influence on any of the civic outcomes. Based on the results, the study recommends that a systematic analysis of the Somali education curriculum be conducted to properly assess the richness and depth of its content in relation to the required standards and coverage of civic education.
\end{abstract}

Keywords: Good citizenship, national identity, civic participation, Somali education, civic outcomes, civic consciousness 


\section{INTRODUCTION}

Somalia is situated in the horn of Africa, bordering the Gulf of Aden, the Indian Ocean, Ethiopia, Kenya, and Djibouti. During its period of colonization, Great Somalia was divided by the colonizers into five regions under the British and Italian protectorates and French Somaliland (Djibouti). If the division had not taken place, the Somali speaking people in the wider Horn of Africa would have formed one of the largest ethnic groups in Africa (Khayre, 2016; Kibble, 2001). Farah (2009) noted that Somali people dwell not only in the recognized Somali state, but also live beyond that border, in countries such as Djibouti, northern Kenya, and Ethiopia.

Somalia gained independence in 1960 and went on to become the present-day Somalia, which is a combination of a former Italian colony and one of the three British protectorates. However, the other two British colonies remained as Ethiopia and Kenya, while French Somaliland (Djibouti) was announced as a separate country in 1977. One year after independence, the state implemented a nationwide referendum that resulted in the adoption of the first national constitution. Hence, a new democratic political system was engendered in the country. This democratic system is considered to be the first violent-free power transfer in the history of the African continent (Khayre, 2016). Nevertheless, this changed when a military coup led by Mohamed Siad Barre in 1969 slaughtered the infant democracy, resulting in the formation of a socialist government dictatorship that ruled the country for more than three decades.

\section{The Somali Education System}

The Somali education system is structured into three levels, namely eight years of primary education, followed by four years of general secondary education and lastly, tertiary education, which lasts for at least three years in some courses and mostly four years in others. According to Abdi (1998) and Abdinoor (2007), before the colonization period, the education system in Somalia was mainly informal--acquired through community-based avenues--and mostly dominated by religious education. However, the arrival of British, Italian and French colonizers in the 19th century resulted in a new formal system alien to the natives and was limited in coverage, as it mainly served the administrative aims and needs of the colonizers. The system primarily aimed to create merely low-skilled workers and labourers out of the natives who would go on to serve as part of the colonizers' administrative machine. Be that as it may, Somalia was able to overcome the setbacks of colonialist education. Its post-colonial era was marked as a period in which the education in Somalia reached its peak in scope and participation. A significant number of educational projects were implemented; adequate educational infrastructure was established; illiteracy campaigns were implemented in 1973 and 1974 in urban and rural areas across the country; nationalized compulsory free primary education was enacted; and official scripts of the Somali language were developed in 1972 (Eno, Eno, Dammak, \& Mweseli, 2014; Mohamed \& Ongubo, 2016; UNESCO, 1981).

However, the outbreak of a civil war in 1991 resulted in severe damage to the education system. In this period, "school enrolment had reached its lowest point, with most if not all 
schools destroyed, materials unavailable, and teachers and students abandoning the educational process" (Cummings \& van Tonningen, 2003, p. vi). Following this, Somali communities revitalized the education system, having recognized it as a fundamental human need, but it was lacking a central government that could manage and oversee its implementation and delivery to the people. The revived education system was privately owned and managed, and has remained as such to this very day (Hussein, 2015). Thus, since the collapse of the central government in 1991, education at all levels has been run privately and is dependent on fees paid by parents for their children (Hussein, 2015). This phenomenon resulted in the adoption of different curricula of different backgrounds (Eno et al., 2014; Hussein, 2015). Therefore, presently no harmonized national curriculum exists in the country at all levels of education, and nearly all member states of the federal government make their own efforts to implement a selfdeveloped curriculum. As a result, there is a lack of standardization and constructive alignment in the development of active citizens with good citizenship attitudes and a strong national identity across the member states, making the formation of Somali civic consciousness and identity an uphill task. Hence, the presence and prevalence of civic consciousness, sense of citizenship, and national identity among Somali students are not known.

\section{LITERATURE REVIEW}

\section{Civic Outcomes and the Roles of Formal and Informal Curricula}

Scholars and community authorities worry that many of today's adolescents are involved in social conflicts, crime, drug abuse, the violation of social values, and severe delinquency (Fairbrother, 2005). Present-day adolescents are observed to have weak social morality and individualistic tendencies; they are seen to be materialistic and disrespectful and are often unable to control themselves and refrain from negative behaviours. The state that present-day adolescents are in is a cause for worry as a nation needs a morally observant youth population to create a foundation for a strong and sustainable nation. This is indeed one of the main challenges that a nation faces in planning for its sustainability and continued existence- the moulding of its youth with desirable traits and characteristics.

To achieve the goals of sustainability, nations and states place their future aspirations on the younger generation of the present age. Nevertheless, they struggle to determine how to properly develop their youth, so the youth can carry the enormous responsibilities and aspirations of their nations when they grow up. In this regard, Torney-Purta and Barber (2005) asserted that schools play a vital role "in the socialization of the next generation's political values" (p. 13). Similarly, Dusi, Steinbach, and Messetti (2012) stated that education plays a vital role in developing firm and resilient citizens who are equipped with modern knowledge to adapt to the inevitable changes taking place around them, as the world has now turned into a hostile and violent place.

Furthermore, the existing literature asserts that the lack of youth involvement in the affairs of their societies, increasing social problems, and ethical dilemmas instigate nations to invest in civic education to facilitate the participation of their children in their communities effectively and efficiently (Isac, Maslowski, \& van der Werf, 2011). In addition, this phenomenon 
encouraged researchers in different locations of the world to study possible ways to find solutions for it. These studies aimed to investigate how active, participative, loyal, and responsible citizens who are reliable citizens of their nation can be developed. However, studies in the field have illuminated differences among countries in the outcomes of civic education of target populations (Schulz \& Sibberns, 2004). The differences result, in part, from the differences in many factors such as home factors, teaching styles, learning approaches at the classroom level, school settings, educational policies, and the practices of different nations (Schulz, 2002; Torney-Purta, Lehmann, Oswald, \& Schulz, 2001).

The term citizenship connotes a collection of social, legal, and civil rights that form the basis of a good life for a community (Gutorov, 2015). Authors have argued that the term does not only concern the rights of an individual, but also includes feelings of obligation and commitment to the nation (Davies, Gregory, \& Riley, 1999). This notion of citizenship is in line with the works of other citizenship researchers (e.g., García-Cabrero, Sandoval-Hernandez, Treviño-Villareal, Ferrans, \& Martinez, 2017) who asserted that citizenship is more profound than voting rights. In fact, it is part of one's fabric of life and civic identity. Therefore, it is not just a legitimate condition, political action, or advocacy; in fact, it is also a natural feeling of belongingness and character which the education system of the nation should embrace and cultivate (Osler \& Starkey, 2006).

\section{Components of Civic Education}

Teaching civic education encompasses four dimensions. First, students are taught about the rights and responsibilities with respect to their government and the law of the country. Second, students will be familiarized with social relationships and the basis upon which these relationships are constructed. Third, students will come to know and appreciate their cultural and historical values and events. And lastly, students will be equipped with productive views as to how they may participate in the economic development of their nation (Audigier, 2000). Similarly, Crick (1998) asserted that the subject entails developing three aspects, namely students' political knowledge, social and moral responsibility, and community involvement.

Since young people are the future of every nation, they should: (a) be moulded to become responsible citizens; (b) actively participate in the community; and (c) promote justice and equality among citizens (Knowles \& Castro, 2019). Indeed, these kinds of citizens can create strong feelings of dependability, a sense of mutual interdependence, and a respectful atmosphere among community members (de Zúñiga, Valenzuela, \& Weeks, 2016). Good citizens of a nation should also be involved in public discourses, show tolerance and respectful understanding of others, stand for solidarity, comply with rules and regulations, and pay national tax contributions (Van Deth, 2013). Thus, for progressive civic development, students should be exposed to regular civic learning opportunities at school in order to enable them to participate in actual civic life (Blevins, LeCompte, \& Wells, 2016; Guilfoile, Delander, \& Kreck, 2014).

The civic outcome of national identity refers to the successful cultivation of national values in the younger generation's sense of self, an awareness among them of national history 
and culture, and the development of a sense of belongingness in their hearts to the nation at all times and in all circumstances (Leonard, 2007; Torney-Purta, Schwille, \& Amadeo, 1999). Also, national identity constitutes a youth's care and affection for his/her country, its historical roots, cultural heritage, customs, and shared principles (Shek, Ma, \& Sun, 2011).

According to Elmi (2016), the presence of three distinct identities in Somali citizens-namely a clan, a national and a religious identity — gives rise to an identity crisis in them, where the clan identity tends to reign superior over the other two. Therefore, Somali citizens prefer to be identified with the names of their clans rather than the name of their nation. Indeed, a Somali's allegiance is to his/her clan, village, and ethnicity, at the expense of the national affiliation (Powell, Ford, \& Nowrasteh, 2008). Having said that, the development of a national sentiment among Somalis is a challenge which the nation's education system should embrace. According to Browne and Fisher (2013), Somalia is deemed to be one of the most highly divided countries in the world. As a result, developing good citizens in Somalia is impeded by the absence of a united nation, as there are issues of clan-based states, a lack of clarity as to whether the nation serves the needs of individuals or clans, and the absence of a feeling of obligation for the nation (Elmi, 2016).

Moreover, the literature demonstrates that formal education has the potential to effectively influence students' civic development by giving them an opportunity to understand how policies and laws affect them and the ways they can assimilate themselves into their community (Serpell, Mumba \& Chansa-Kabali, 2011; Torney-Purta et al., 2001). In addition, where civic education is concerned, formal curriculum is a significant element that influences its outcomes (Kennedy, 2019). Important aspects of the curriculum include timetables, the availability of appropriate and sufficient extra-curricular activities, and transition policies that determine the expected learning outcomes and completion levels (Eccles \& Roeser, 2009). Other studies added that assimilation activities--such as student government, civic extracurricular activities, and visits to local government establishments by the students--also tend to have positive results on civic outcomes (Kahne, Chi, \& Middaugh, 2006). Similarly, other essential factors for progressive civic development include teacher preparatory processes, school management, school ethos, classroom climate and teachers' pedagogical practices that promote open classrooms, as well as the sufficient time allocation for both formal and informal curricular activities (Kennedy, 2019).

However, current literature points to an existence of a number of issues in studying civic curricula. In this regard, Torney-Purta et al. (2001) asserted that civic content in a formal curriculum is less emphasized and less defined in comparison to other traditional subjects such as science, mathematics, and history. This is due to the unpredictability of civic knowledge, which is attributable to its multidisciplinary nature and teacher-related factors (Torney-Purta et al., 2001). Similarly, Mouritsen and Jaeger (2018) argued that it is not an easy task to identify suitable curriculum programs and instructional strategies that can be employed and to assess the success levels of students. This, in part, is due to the differences in the underlying aims of each program, how to operationalize them, and the school-specific cultures and ethos (TorneyPurta et al., 2001).

Furthermore, although curriculum approaches and pedagogical strategies have been reported to exercise a positive influence on civic outcomes, their influence is rarely studied 
(Black, Stokes, Turnbull, \& Levy, 2009). Taking into account this research gap, this study will consider the curriculum aspects of civic education. In this regard, Kerr (1999) considered civic curriculum to be more comprehensive than formal curriculum as it encompasses school ethos, hidden curriculum, extra-curricular activities, and students' daily interactions in their lives.

\section{Gender Differences in Civic Outcomes}

The existing literature has revealed gender differences in many civic aspects. In this regard, some previous studies have noted that female students are more likely to engage in social issues and acquire more civic knowledge than male students (Cicognani, Zani, Fournier, Gavray, \& Born, 2012; Flanagan, Bowes, Jonsson, Csapo, \& Sheblanova, 1998; Zaff, Malanchuk, \& Eccles, 2008). Other researchers found that male and female adolescents differ in their support of human rights, social justice, political efficacy, interest in volunteerism, and other civic activities (Hart \& Wandeler, 2018; Knowles, Torney-Purta, \& Barber, 2018). Female students tend to excel in the areas of human rights, social justice and volunteerism, while male students are more likely to have high performance in political efficacy. In addition, Hart and Wandeler (2018) studied the impact of civic service learning on students' civic outcomes, and found the existence of gender differences in the outcomes of both civic competence and civic commitment, in favour of female students. Therefore, where the review of this body of literature is concerned, there appears to be an association between gender and students' civic outcomes (Keating \& Janmaat, 2015).

However, Makri (2019) found conflicting results pointing to gender equality in certain civic outcomes, where male and female students demonstrated the same level of consciousness in civic responsibilities, while differing in the levels of political awareness, civic action and leadership skills. These results point to the existence of gender differences in some civic outcomes, but not in others. The disparities that have been found call for further investigation into important civic outcomes, such as good citizenship, national identity and civic participation etc, to enable a proper planning for their inclusion into the formal and informal curricula.

\section{Influence of Parental Education in Civic Outcomes}

Current literature has revealed the influence of background factors on students' civic development where students from less educated families tend to show limited civic knowledge (Jama \& Al-Hidabi, 2020; Torney-Purta et al., 2001). In contrast, parents with sufficient education level have a greater potential to influence the civic knowledge acquired by their children to enable them to participate better in their communites (Bischoff, 2016). In addition, scholars have also argued that civic development is a product of students' interaction with the outside environment that surrounds them (Keating \& Janmaat, 2015; Zaff et al., 2008).

Similarly, Lenzi et al. (2012) argued that parents with good socio-economic standings are likely to be interested in social relationships and connections, and are more inclined towards organizations that engage young people in the lives and affairs of their communities. 
Consequently, youths who come from more economically stable families tend to receive more assistance and encouragement to participate in the civic activities conducted by organizations outside their school settings. Needless to say, more well-off families have a greater ability to pay for the costs of their children's participation in such activities. Hence, the family factor and a host of other external agents--such as the school, peer groups and neighbours--exert an influence on the citizenship development of students (Rossi, Lenzi, Sharkey, Vieno \& Santinello, 2016; Schulz, Ainley, Fraillon, Kerr, \& Losito, 2010).

\section{Research Objectives and Question}

The historical trajectory of the country has lent importance to the present study, which aimed to address the role that the Somali school curriculum, gender and parental education can play in building students' sense of citizenship and national identity. In line with this, the study investigated whether the present curriculum equips learners with good citizenship attitudes and a sense of national identity so that they acquire the potential to participate effectively in the affairs of society. In line with its objective, the present study addressed the following research question:

Are formal and informal curriculum, gender and parental education statistically significant predictors of students' good citizenship, national identity and civic participation?

Despite the fact that various studies have addressed some aspects of the above question, none of them has studied the specific influence of school curriculum in developing citizenship, national identity, and the civic participation of students. Therefore, this study addressed these variables in detail within the Somali context. 


\section{METHODOLOGY}

\section{Sample}

The respondents were drawn from a Form Four secondary school student population in Somalia. A total of 400 learners in the final year of their schooling period participated in the study. Table 1 shows a descriptive analysis of the respondents.

Table 1

Demographic Description of the Respondents $(\mathrm{N}=400)$

\begin{tabular}{|c|c|c|c|}
\hline & Description & $\mathbf{n}$ & $\%$ \\
\hline Gender & $\begin{array}{ll}\text { - } & \text { Male } \\
\text { - } & \text { Female }\end{array}$ & $\begin{array}{l}237 \\
163\end{array}$ & $\begin{array}{l}59.2 \\
40.8\end{array}$ \\
\hline Age & $\begin{array}{ll}\text { - } & \text { Below } 14 \\
\text { - } & 15-19 \\
\text { - } & 20-24 \\
\text { - } & 25-29 \\
\text { - } & \text { Above } 30\end{array}$ & $\begin{array}{c}6 \\
295 \\
95 \\
2 \\
2 \\
\end{array}$ & $\begin{array}{c}1.5 \\
73.8 \\
23.8 \\
.5 \\
.5\end{array}$ \\
\hline $\begin{array}{l}\text { Level of Education } \\
\text { Expected to be Obtained }\end{array}$ & $\begin{array}{l}\text { - } \text { Secondary } \\
\text { - Bachelor's degree } \\
\text { - } \text { Master's } \\
\text { - } \text { PhD } \\
\end{array}$ & $\begin{array}{c}14 \\
2 \\
53 \\
331 \\
\end{array}$ & $\begin{array}{c}3.5 \\
0.5 \\
13.3 \\
82.8 \\
\end{array}$ \\
\hline & Total & 400 & $100 \%$ \\
\hline
\end{tabular}

Male students made up 59.2\% of the sample, outnumbering female students who comprised $40.8 \%$. A majority of the students were in the 15 to 19 -year age group (73.8\%), followed by the 20 to 24 -year age group (23.8\%). With regard to expected level of education, $82.8 \%$ of the respondents chose $\mathrm{PhD}$ as the level they expected to reach in the education ladder, while $13.3 \%$ indicated the master's level as their final target. Another 3.5\% of the students reported that they would not pursue further education beyond the secondary level.

\section{Instruments}

The study utilized two instruments (i.e., one adapted and one self-developed) with 51 items to measure the study's five constructs, i.e., good citizenship, national identity, civic participation, formal curriculum and non-formal curriculum. The background variables and the constructs of good citizenship and national identity were adapted from Schulz and Sibberns (2004). The items on formal school curriculum and civic participation were sourced from Brese, Jung, Mirazchiyski, Schulz and Zuehlke (2011), while those measuring non-formal curriculum were self-developed by the researchers. All constructs were assessed on a six-point Likert scale of different categories of scaling (Table 2). 
Table 2

Sample Items and Scaling Categories Used in the Questionnaire

\begin{tabular}{|c|c|c|}
\hline Construct & Sample Items & Scaling \\
\hline $\begin{array}{l}\text { 1. Good } \\
\text { Citizenship } \\
\text { (13 items) }\end{array}$ & $\begin{array}{l}\text { How important are the following behaviours for being a } \\
\text { good adult citizen? } \\
\text { a) always obeying the law } \\
\text { b) serving in the military to defend the country }\end{array}$ & $\begin{array}{l}\text { Degree of Importance: } \\
\text { Not At All Important to } \\
\text { Very Extremely } \\
\text { Important }\end{array}$ \\
\hline $\begin{array}{l}\text { 2. National } \\
\text { Identity } \\
\text { (13 items) }\end{array}$ & $\begin{array}{l}\text { How much do you agree or disagree with the following } \\
\text { statements about your country? } \\
\text { a) The flag of the country is important to me } \\
\text { b) As a Somali citizen, I take my responsibility } \\
\text { seriously }\end{array}$ & \\
\hline $\begin{array}{l}\text { 3. Non-formal } \\
\text { Curriculum } \\
\text { (8 items) }\end{array}$ & $\begin{array}{l}\text { How much do you agree or disagree with the following } \\
\text { statements? } \\
\text { a) During school holidays, I participate in } \\
\text { activities organized by the local community } \\
\text { b) My friends and I are always concerned about } \\
\text { the challenges facing our country }\end{array}$ & $\begin{array}{l}\text { Strongly Disagree to } \\
\text { Strongly Agree }\end{array}$ \\
\hline $\begin{array}{l}\text { 4. Formal } \\
\text { Curriculum } \\
\text { (10 items })\end{array}$ & $\begin{array}{l}\text { How much have you learned about the following topics } \\
\text { at your school? } \\
\text { a) How to be a patriotic and loyal citizen of the } \\
\text { country } \\
\text { b) The national constitution }\end{array}$ & $\begin{array}{l}\text { Degree of Learning: } \\
\text { Not At All to A Lot }\end{array}$ \\
\hline $\begin{array}{l}\text { 5. Civic } \\
\text { Participation } \\
\text { (7 items) }\end{array}$ & $\begin{array}{l}\text { How well do you think you would do the following } \\
\text { activities? } \\
\text { a) Joining an organisation for a political or social } \\
\text { cause } \\
\text { b) Giving to charity organizations to help needy } \\
\text { people in the community }\end{array}$ & $\begin{array}{c}\text { Degree of Confidence } \\
\text { Not At All to Extremely } \\
\text { Very Well }\end{array}$ \\
\hline
\end{tabular}

\section{Data Collection and Analysis}

The data were collected directly by the first researcher who visited the research sites (i.e., twelve secondary schools in the selected rural and urban areas in three zones of the country, namely Somaliland, Puntland and South Central) and made direct contact with the research sample. The twelve schools were equally distributed among the three zones. In addition, the schools were drawn from three categories, namely community-owned schools (4 schools), private schools (4 schools), and public schools (4 schools).

The data were analysed using the IMB Statistical Package for Social Science (SPSS) version 26. Prior to running inferential statistics, the researcher checked the missing values and the normality of the data. The data had no missing values, so no further checking was required. To investigate normality, the values of skewness and kurtosis were checked. Curran, West, and Finch (1996) suggested that absolute values of $>2$ for skewness and $>7$ for kurtosis are acceptable to indicate normality. Thus, as shown in Table 3, the normality assumption of the five variables was met. 
Table 3

Tests of Normality and Reliability $(\mathrm{N}=400)$

\begin{tabular}{lccccccc}
\hline & Min & Max & M & SD & Skewness & Kurtosis $\begin{array}{c}\text { Cronbach's } \\
\text { Alpha }\end{array}$ \\
\hline Good Citizenship & 34.00 & 78.00 & 59.88 & 8.26 & -.21 & .03 & .69 \\
National Identity & 13.00 & 78.00 & 56.66 & 8.03 & -.82 & 4.33 & .62 \\
Formal Curriculum & 10.00 & 60.00 & 42.83 & 11.96 & -.61 & -.46 & .77 \\
Non-Formal Curriculum & 8.00 & 48.35 & 33.68 & 8.90 & -.46 & -.49 & .87 \\
Civic Participation & 7.00 & 42.00 & 30.76 & 7.59 & -.48 & -.35 & .79 \\
Gender & 1 & 2 & 1.41 & .49 & .38 & -1.87 & - \\
Parental Education & 2.00 & 12.00 & 7.28 & 2.72 & -.22 & -.57 & - \\
\hline
\end{tabular}

Summated scores for the constructs were obtained by adding up the responses to all items measuring each of the constructs. Using the summated scores, a set of multiple regression analysis was then run to assess the relative influences of the four predictor variables (i.e., formal curriculum, non-formal curriculum, gender and parental education level) on the three criterion measures (i.e., students' civic outcomes--good citizenship, national identity and civic participation).

\section{RESULTS}

This study was conducted to examine if formal and non-formal school curriculum, gender and parental level of education would influence Somali students' sense of good citizenship and national identity and encourage their civic participation in the affairs of their communities. It was hypothesized that both formal and non-formal curricula would positively predict students' good citizenship, national identity and civic participation. To test this hypothesis, a multiple regression analysis was used. MRA's assumptions of linearity, normality, and uncorrelated errors were first checked and met.

\section{Predictors of Good Citizenship}

A multiple regression was conducted to identify the best linear combination of gender, parental education, and formal and non-formal curriculum in predicting the good citizenship of Form Four Somali students. The mean, standard deviation, and intercorrelations are shown in Table 4.

Table 4

Means, Standard Deviation, and Intercorrelations for Good Citizenship and Predictor Variables $(\mathrm{N}=400)$

\begin{tabular}{lcccccc}
\hline \multicolumn{1}{c}{ Variable } & M & SD & $\mathbf{1}$ & $\mathbf{2}$ & $\mathbf{3}$ & $\mathbf{4}$ \\
\hline Good Citizenship & 59.88 & 8.26 & .22 & .16 & .01 & .05 \\
Predictor Variables & & & & & & \\
- Formal Curriculum & 42.83 & 11.96 & - & .54 & .01 & -.18 \\
- Non-Formal Curriculum & 33.68 & 8.90 & & - & .03 & -.15 \\
- Parental Education & 7.29 & 2.72 & & & - & -.08 \\
- Gender & 1.41 & .49 & & & - \\
\hline les: 1 = Formal Curriculum; 2 = Non-formal Curriculum; 3 = Parental Education; 4 = Gender
\end{tabular}

Notes: 1 = Formal Curriculum; $2=$ Non-formal Curriculum; $3=$ Parental Education; $4=$ Gender 
The combination of the variables significantly predicted good citizenship, F (4=395) = 6.361, $p<.001$. In this model, gender and formal curriculum significantly contributed to the prediction. $\mathrm{R}$ Square $(\mathrm{R})$ was used to see how much the predictors contributed towards explaining the outcome. In this analysis, the value of R-Square was $0.061(6 \%)$. This indicates that taken together, the four predictors contributed $6 \%$ towards good citizenship. The beta results shown in Table 5 suggest that formal curriculum had the highest degree of contribution to the prediction with $20 \%$, followed by gender with $10 \%$. Thus, based on the above values, this model provides a good fitting model for good citizenship.

Table 5

Predictors of Good Citizenship: MRA Summary Statistics $(\mathrm{N}=400)$

\begin{tabular}{lcccc}
\hline \multicolumn{1}{c}{ Variable } & B & SEB & $\boldsymbol{\beta}$ & p \\
\hline Formal curriculum & .14 & .04 & .20 & .001 \\
Non-formal curriculum & .06 & .05 & .06 & .271 \\
Parental education & .04 & .15 & .01 & .768 \\
Gender & 1.67 & .84 & .10 & .047 \\
Constant & 50.53 & 2.22 & & .000 \\
\hline
\end{tabular}

\section{Predictors of National Identity}

This part of the analysis aims to determine the best linear combination of gender, parental level of education, and formal and non-formal curriculum for predicting Form Four Somali students' national identity. The MRA revealed that the combination of the variables significantly predicted national identity, $\mathrm{F}(4,395)=26.332, \mathrm{p}<.001$. The results also showed that gender, formal curriculum, and non-formal curriculum significantly contributed to national identity. $R$ Square $(\mathrm{R})$ indicates how much the predictors cumulatively contribute towards explaining the outcome and is always converted into a percentage. In this analysis, the value of R-Square was $0.211(21.1 \%)$, which indicates that taken together, the four predictors positively contributed 21.1\% towards Somali students' national identity. As shown in Table 7, the non-formal curriculum is the highest predictor of national identity ( $p<.000$ ), followed by formal curriculum $(p<.001)$ and gender $(p<.007)$. These results statistically provide a good fitting model for national identity. In Table 6, the mean, standard deviation, and intercorrelations are shown.

Table 6

Means, Standard Deviation and Intercorrelations for National Identity and Predictor Variables $(\mathrm{N}=400)$

\begin{tabular}{lcccccc}
\hline \multicolumn{1}{c}{ Variable } & M & SD & $\mathbf{1}$ & $\mathbf{2}$ & $\mathbf{3}$ & $\mathbf{4}$ \\
\hline National Identity & 56.66 & 8.03 & .34 & .42 & .01 & .04 \\
Predictor Variable & & & & & & \\
- Formal Curriculum & 42.83 & 11.96 & - & .54 & .09 & -.18 \\
- Non-Formal Curriculum & 33.68 & 8.90 & & - & .03 & -.15 \\
- Parental Education & 7.29 & 2.72 & & & - & -.08 \\
- Gender & 1.41 & .49 & & & - \\
\hline : & Formal Curriculum; 2 = Non-formal Curriculum; 3 = Parental Education; $4=$ Gender
\end{tabular}

Notes: 1 = Formal Curriculum; $2=$ Non-formal Curriculum; $3=$ Parental Education; $4=$ Gender 
Table 7

Predictors of National Identity: MRA Summary Statistics $(\mathrm{N}=400)$

\begin{tabular}{lcccc}
\hline \multicolumn{1}{c}{ Variable } & B & SEB & $\boldsymbol{\beta}$ & p \\
\hline Formal Curriculum & .12 & .04 & .18 & .001 \\
Non-formal curriculum & 31 & .05 & .35 & .000 \\
Parental education & .01 & .13 & .00 & .923 \\
Gender & 2.04 & .75 & .13 & .007 \\
Constant & 39.36 & 1.98 & & .000 \\
\hline
\end{tabular}

From Table 2, it can be seen that the majority responses given by the Yemeni students to all items on perceived knowledge of IALL are either neutral or agree. Specifically, when asked whether they knew a variety of IALL tools, a majority of them (75\%) picked either neutral or agree as their response. The mean value for item 1 is 3.39. Similarly, Item 2 that sought to ascertain the students' perceived knowledge of IALL websites collected most neutral and agree responses $(65 \%)$ with a mean score of 3.07. On the other hand, a somewhat varied response was found on students' rating of their expert knowledge on IALL; even though a majority still responded neutral or agree $(60 \%)$, but almost $20 \%$ of the sample disagreed they knew about IALL websites, with $12 \%$ strongly disagreeing to the statement. The mean score for Item 3 is 3.00. For Item 4 which sought responses indicating knowledge on IALL compared to colleagues, $35 \%$ chose neutral, while $24 \%$ disagreed and $36 \%$ agreed. Only a small percentage strongly agreed $(5 \%)$ they knew more about IALL than their colleagues or peers. Hence, the mean value for Item 4 is 2.74 , which indicates disagreement. Finally, Item 5 (knowing a great deal about IALL), 34\% indicated neutral, while a somewhat balanced number either agreed or disagreed they knew a great about IALL, with $18 \%$ strongly disagreeing they had much knowledge of it at all. The mean score for Item 5 is 2.79 (indicating a disagreement). The mean agreement for perceived knowledge of IALL is 3.00. This shows that on average, the students tend to rate their knowledge in the neutral category bordering on disagreement that they knew

\section{Predictors of Civic Participation}

A multiple regression was conducted to identify the best linear combination of gender, parental education, formal and non-formal curricula for predicting the civic participation of students. The assumptions of linearity, normality, and uncorrelated errors were checked and met. The mean, standard deviation, and intercorrelations are shown in Table 8.

Table 8

Means, Standard Deviation, and Intercorrelations for Civic Participation and Predictor Variables $(\mathrm{N}=400)$

\begin{tabular}{lcccccc}
\hline \multicolumn{1}{c}{ Variable } & M & SD & $\mathbf{1}$ & $\mathbf{2}$ & $\mathbf{3}$ & $\mathbf{4}$ \\
\hline Civic Participation & 56.66 & 8.03 & .32 & .45 & -.03 & -.01 \\
Predictor Variable & & & & & & \\
- Formal curriculum & 42.83 & 11.96 & - & .54 & .01 & -.18 \\
- Non-formal curriculum & 33.68 & & & - & -.03 & -.15 \\
& - Parental education & 7.29 & 2.72 & & - & -.08 \\
& - Gender & 1.41 & .49 & & & - \\
Notes: 1 = Formal Curriculum; 2 = Non-formal Curriculum; 3 & Parental Education; 4 = Gender
\end{tabular}


In this regression, the combination of the variables significantly predicted civic participation, $\mathrm{F}$ $(4,395)=27.462, p<.001$ with formal and non-formal curriculum significantly contributing to the prediction. $\mathrm{R}$ Square $(\mathrm{R})$ indicates how much the predictors contributed to civic participation. In this analysis, the value of R-Square was $0.218(22 \%)$. This means that taken together, the four predictors explained about $22 \%$ of Somali students' civic participation. The beta weights shown in Table 9 suggest that non-formal curriculum contributes the most to civic participation, followed by formal curriculum. These results provide a good fitting model for civic participation.

Table 9

Predictors of Civic Participation: MRA Summary Statistics $(\mathrm{N}=400)$

\begin{tabular}{lcccc}
\hline \multicolumn{1}{c}{ Variable } & B & SEB & $\boldsymbol{\beta}$ & $\mathbf{p}$ \\
\hline Formal curriculum & .08 & .03 & .12 & .027 \\
Non-formal curriculum & .34 & .05 & .40 & .000 \\
Parental education & -.1 & .12 & -.04 & .425 \\
Gender & .93 & .70 & .06 & .185 \\
Constant & 21.31 & 1.86 & & .000 \\
\hline
\end{tabular}

\section{DISCUSSION}

The present study examined the influence of four predictor variables, i.e., curriculum (formal and non-formal), parental education and gender, on Somali students' civic outcomes (i.e., good citizenship, national identity, and civic participation). It found that curriculum exercised a significant influence on all civic outcomes, while parental education did not have a statistically significant impact on any of the outcomes. In contrast to parental education, gender significantly predicted good citizenship and national identity, while having no influence on civic participation. The study revealed that the combination of all the predictor variables significantly predicted the outcomes, with curriculum being a statistically significant contributor. This result suggests that curriculum plays an important role in developing Somali students' sense of citizenship and national identity, thereby promoting their civic participation.

The fact that formal curriculum significantly predicted all of the civic outcomes is not surprising, as formal curriculum is an important aspect in teaching civic education (Kennedy, 2019). In support of the role of curriculum in nation building, Ross (2007) stated that "school curricula helped generate national and group identity through promulgating national myths and heroes as embodiments of "national character" (p. 123). Yet, for a progressive civic development to occur, several factors need to be carefully planned in the entire education setup, such as teacher preparatory processes, school management, school ethos, classroom environment and teachers' pedagogical practices that promote open classrooms, as well as sufficient time allocation for both formal and informal curricular activities.

The results also revealed that non-formal curriculum significantly predicted students' national identity and their civic participation. Conceptually, the idea and scope of curriculum are very wide. It goes beyond the formal curriculum as it encompasses not just the intended content knowledge and skills, but also the school ethos, hidden curriculum, extra-curricular activities, and daily students interactions in their lives (Kerr, 1999). Keating and Janmaat (2015) 
asserted that developing students' civic awareness only through the formal school curriculum is not enough. Students should be given opportunities to put their civic knowledge into practice in non-formal, co-curricular activities. The reason for this is these extra-curricular experiences and practices at school will likely develop in students the ability to work for the betterment of their society and their nation as a whole when they graduate and enter adulthood.

Other studies suggested that in order to facilitate the proper and healthy participation of students when they become adults, students should be exposed to and should engage in civic activities at the actual learning sites (Blevins et al., 2016). This is in line with the recommendations made by other studies that schools should teach students their roles as prospective citizens, their rights and responsibilities in this capacity, how to challenge unjust actions, and obey and defend laws (Blasko, da Costa, \& Vera-Toscano, 2018; Martin \& Chiodo, 2007).

However, the study demonstrated that non-formal curriculum did not significantly predict the civic outcome of good citizenship. Citizenship attitudes are essential civic behaviours which entail that citizens are prepared to objectively assess the diverse viewpoints, examine appropriate approaches for change and reform, and concentrate on matters of social justice, equality and participation (Geboers, Geijsel, Admiraal, \& ten Dam, 2013). With good citizenship attitudes, citizens accept, tolerate and respect differences in culture, ethnicity and status, and consider this as an individual's right. They also advocate for the democratic values and practices which are necessary for a proper functioning democracy and its institutions. And, they become involved in community affairs voluntarily and promote social solidarity for a common good (Eidhof, ten Dam, Dijkstra \& van de Werfhorst, 2016). As such, the reason behind the lack of relationship between non-formal curriculum and good citizenship is not wellunderstood and needs further investigation.

Due to the low female enrolment rates in secondary education, i.e., 38.8\% in Somaliland, $36 \%$ in Puntland, and $40.5 \%$ in South Central (Jama \& Barre, 2019), the number of female students in Somalia is lower than that of male students. Despite this disparity, the study found that gender had a significant influence on good citizenship and national identity, while it lacked an influence on civic participation. The mixed results are supported by what has been found in previous studies--that there are gender differences in some civic outcomes, while in some others, no gender disparities were discovered.

It is noteworthy to point out that the observed influence of parental education on civic outcomes was somewhat different from the findings of previous research. According to TorneyPurta et al. (2001), children whose parents attained a lower level of education possessed negligible civic knowledge compared to those from well-educated families. Similarly, educated parents are in a better position to influence the type of civic content exposed to their children (Bischoff, 2016). In particular, socially participative parents are likely to encourage their children to develop positive civic attitudes and political involvement (Zaff et al., 2008). The results of previous studies confirmed the influence that parental education has on students' civic development. However, in this study, parental education was found to have no effect on any of the civic outcomes. These results might have been influenced by the research site, sample size as well as the target population. Thus, the findings of this study conflict with the existing 
research literature on students' civic development and outcomes, which invites further investigation into the issue in order to reconcile or make sense of these results.

\section{CONCLUSION AND RECOMMENDATIONS}

The present study investigated whether curriculum (formal and non-formal) along with gender and parental education as demographic variables predicted students' civic outcomes. Based on the MRA results, it concluded that formal curriculum contributed to the civic development of students and equips them with good citizenship and a sense of national identity, and hence, paves the way for progressive civic participation in the future. However, it revealed that the non-formal part of the curriculum had a statistically significant influence only on the outcomes of national identity and civic participation. The study also discovered significant gender differences in Somali students' national identity and good citizenship, but not in their civic participation. Parental education was not found to be a significant predictor of any of the civic outcomes. Lastly, the study concluded that a combination of the four independent variables significantly predicted civic outcomes.

In civic studies, it is a common practice to widen the research scope by including factors like school management and teaching personnel. Therefore, further research on the impact of the school and teachers on students' civic outcomes is recommended. Another factor to be considered is the population being studied. The present study's target population was students in their final year of schooling; thus, increasing the participation of students from other years of schooling will enable proper comparisons of civic outcomes to be made, and will help the creation of timely solutions to civic development issues in case less than desirable results are found in future research.

Apart from that, the study recommends a curriculum content analysis to be conducted as the scope of the study did not assess the richness and depth of the Somali curriculum in relation to the required standards and contents of civic education. In addition, due to the importance and weight of the subject, the study recommends that the content of the Somali civic curriculum be imparted using a single-subject approach, instead of the integrated approach commonly used in social studies. Finally, as teachers and school administrations are the central agents of proper civic development in students, the study suggests running adequate training for civic education teachers, as well as for the school management, on the recent changes and emerging issues within the society to help them translate the issues into meaningful classroom activities and discussion. 


\section{REFERENCES}

Abdi, A. A. (1998). Education in somalia: History, destruction, and calls for reconstruction. Comparative Education, 34(3), 327-40.

Abdinoor, A. S. (2007). Constructing education in a stateless society: The case of somalia. (Publication No. ohiou1173755011) [Doctoral Dissertation, Ohio University, USA]. OhioLINK Electronic Theses and Dissertations Center. Retrieved from https://etd.ohiolink.edu/

Audigier, F. (2000). Basic concepts and core competencies for education for democratic citizenship. Geneva: Council of Europe Strasbourg. Retrieved from http://www.ibe.unesco.org/fileadmin/user_upload/Curriculum/SEEPDFs/audigier.pdf.

Bischoff, K. (2016). The civic effects of schools: Theory and empirics. Theory and Research in Education, 14(1), 91-106.

Black, R., Stokes, H., Turnbull, M.J., \& Levy, J. (2009). Civic participation through the curriculum. Youth Studies Australia, 28(3), 13-20.

Blasko, Z., da Costa, P. D., \& Vera-Toscano, E. (2018). Civic attitudes and behavioural intentions in the 2016 international civic and citizenship education study (iccs): New evidence for education and training policies in europe. Publications Office of the European Union: Luxembourg. doi:10.2760/218931, JRC109480.

Blevins, B., LeCompte, K., \& Wells, S. (2016). Innovations in civic education: Developing civic agency through action civics. Theory and Research in Social Education, 44(3), 344384.

Brese, F., Jung, M., Mirazchiyski, P., Schulz, W., \& Zuehlke, O. (2011). ICCS 2009 user guide for the international database: Supplement 3. IEA: Amsterdam. https://files.eric.ed.gov/fulltext/ED544617.pdf

Browne, E., \& Fisher, J. (2013). Key actors mapping: Somalia. Birmingham, UK: GSDRC Rapid Literature Review, University of Birmingham.

Cicognani, E., Zani, B., Fournier, B., Gavray, C., \& Born, M. (2012). Gender differences in youths' political engagement and participation: The role of parents and of adolescents' social and civic participation. Journal of Adolescence, 35(3), 561-576.

Crick, B. (1998, September 22). Education for citizenship and the teaching of democracy in schools: Final report of the advisory group on citizenship. Qualifications and Curriculum Authority. https://dera.ioe.ac.uk/4385/1/crickreport1998.pdf

Cummings, W. K., \& van Tonningen, L. R. (2003). Somalia education sector assessment: With special attention to northwest zone. US Agency for International Development. http://www.beps.net/publications/somaliaeducationsectorassessmentfinalreport.doc.pd

Curran, P.J., West, S.G., \& Finch, J.F. (1996). The robustness of test statistics to nonnormality and specification error in confirmatory factor analysis. Psychological Methods, 1(1), 1629. 
Davies, I. Gregory, I., \& Riley, S.C. (1999). Good citizenship and educational provision (p. 24). London: Falmer Press.

Dusi, P., Steinbach, M., \& Messetti, G. (2012). Citizenship education in multicultural society: Teachers' practices. Procedia-Social and Behavioral Sciences, 69, 1410-1419. doi:10.1016/j.sbspro.2012.12.080

de Zúñiga, H.G., Valenzuela, S., \& Weeks, B. E. (2016). Motivations for political discussion: Antecedents and consequences on civic engagement. Human Communication Research, 42(4), 533-552. doi:10.1111/hcre.12086

Eccles, J. S, \& Roeser, R. W. (2009). Schools, academic motivation, and stage-environment fit. In R.M. Lerner \& L. Steinberg (Eds.), Handbook of Adolescent Psychology (Vol. 1) (pp 404-434). John Wiley \& Sons, Inc. https://doi.org/10.1002/9780471726746.ch5

Eidhof, B. B. F., ten Dam, G., Dijkstra A. B., \& van de Werfhorst, H. G. (2016). Consensus and contested citizenship education goals in western europe. Education, Citizenship and Social Justice, 11(2), 114-129. doi:10.1177/1746197915626084

Elmi, A. A. (2016). Developing an inclusive citizenship in somalia: Challenges and opportunities. Bildhaan: An International Journal of Somali Studies, 16(7), 6-20.

Eno, M. A., Eno, O. A., Dammak, A., \& Mweseli, M. N. W. (2014). Somalia: An overview of primary and secondary education. Journal of Somali Studies, 1(1), 11-33.

Fairbrother, G. P. (2005). Power and right in hong kong's citizenship education. Citizenship Studies, 9(3), 293-308.

Farah, A. O. (2009). Diaspora involvement in the development of somalia. Institut for Historie, Internationale Studier og Samfundsforhold, Aalborg Universitet. http://vbn.aau.dk/ws/ portalfiles/portal/16987635/diiper_wp_13.pdf

Flanagan, C. A., Bowes, J. M., Jonsson, B., Csapo, B., \& Sheblanova, E. (1998). Ties that bind: Correlates of adolescents' civic commitments in seven countries. Journal of Social Issues, 54(3), 457-475. Retrieved from https://core.ac.uk/download/pdf/80852167.pdf

García-Cabrero, B., Sandoval-Hernandez, A., Treviño-Villareal, E., Ferrans, S. D., \& Martinez, M. G. P. (2017). Affective and cognitive processes as determinants of civic participation in latin american countries. In B. García-Cabrero, A. Sandoval-Hernández, E. TreviñoVillareal, S. D. Ferráns \& M. G. P. Martínez (Eds.), Civics and citizenship: Theoretical models and experiences in Latin America (pp 129-153). SpringerLink. https://doi.org/10.1007/978-94-6351-068-4.

Geboers, E., Geijsel, F., Admiraal, W., \& ten Dam, G. (2013). Review of the effects of citizenship education. Educational Research Review, 9, 158-73. doi:10.1016/j.edurev.2012.02.001_

Guilfoile, L., Delander, B., \& Kreck, C. (2016). Guidebook: Six proven practices for effective civic learning. USA: Education Commission of the States. Retrieved from https://www.ecs.org/six-proven-practices-for-effective-civic-learning/

Gutorov, V. (2015). Citizenship, national identity and political education: Some disputable questions. Studies of Transition States and Societies, 7(1), 77-93. 
Hart, S., \& Wandeler, C. (2018.) The impact of action civics service-learning on eighth-grade students' civic outcomes. International Journal of Research on Service-Learning and Community Engagement, 6(1), 1-17.

Hussein, A. S. A. (2015). Educational challenges in post-transitional somalia: Case study. Mogadishu. Mogadishu, Somalia: The Heritage Institute for Policy Studies. http://goobjoog.com/english/wp-content/uploads/2015/04/4.5_Education_ENG_small_ v2. pdf

Isac, M. M., Maslowski, R., \& van der Werf., G. (2011). Effective civic education: An educational effectiveness model for explaining students' civic knowledge. School Effectiveness and School Improvement, 22(3), 313-333. http://dx.doi.org/10.1080/09243453.2011.571542

Jama, A. H., \& Dawood, A. Y. A. (2020). Examining the influence of selected demographic variables on selected civic outcomes. International Journal of Education, Humanities and Social Science, 3(4), 263-281

Jama, A., \& Barre, G. S. (2019). Understanding the barriers to girls' and women's access to higher education in puntland, somalia: A video and blogging project. ALIGN. https://media.africaportal.org/documents/GN_Policy_Brief.pdf.

Kahne, J., Chi, B., \& Middaugh, E. (2006). Building social capital for civic and political engagement: The potential of high-school civics courses. Canadian Journal of Education, 29(2), 387-409.

Keating, A., \& Janmaat, G. J. (2015). Education through citizenship at school: Do school activities have a lasting impact on youth political engagement? Parliamentary Affairs, 69(2), 409-29.

Kennedy, K.J. (2019). Civic and citizenship education for the future. In: Civic and Citizenship Education in Volatile Times (pp. 45-63). Springer: Singapore. https://doi.org/10.1007/9 78-981-13-6386-3_4

Kerr, D. (1999). Citizenship education in the curriculum: An international review. School Field, $10(3 / 4), 5-32$.

Khayre, A.A.M. (2016, April 27). Somalia: An overview of the historical and current situation. Social Science Research Network (SSRN). http://dx.doi.org/10.2139/ssrn.2771125

Kibble, S. (2001). Somaliland: Surviving without recognition; Somalia: Recognised but failing. International Relations, 15(5), 5-25.

Knowles, R. T., \& Castro, A, J. (2019). The implications of ideology on teachers' beliefs regarding civic education. Teaching and Teacher Education, 77, 226-239.

Knowles, R. T., Torney-Purta, J., \& Barber, C. (2018). Enhancing citizenship learning with international comparative research: Analyses of iea civic education datasets. Citizenship Teaching and Learning, 13(1), 7-30. doi:10.1386/ctl.13.1.7_1

Lenzi, M., Vieno, A., Perkins, D. D., Santinello, M., Elgar, F. J., Morgan, A., \& Mazzardis, S. (2012). Family affluence, school and neighborhood contexts, and adolescents' civic engagement: A cross-national study. American Journal of Community Psychology, 50 (12), 197-210. doi: 10.1007/s10464-012-9489-7 
Leonard, M. (2007). Children's citizenship education in politically sensitive societies. Childhood, 14(4), 487-503. https://doi.org/10.1177/0907568207086411.

Makri, E. (2019). A promising connection: Increasing civic life learning through simulated civics education action. International Journal for Cross-Disciplinary Subjects in Education, 10(4), 4169 -4180. Retrieved from https://infonomics-society.org/wpcontent/uploads/A-Promising-Connection.pdf.

Martin, L. A., \& Chiodo, J. J. (2007). Good citizenship: What students in rural schools have to say about it. Theory \& Research in Social Education, 35(1), 112-134.

Mohamed, A. M., \& Ongubo, J. M. (2016). Primary school enrolment in somalia: What are the enabling or hindering factors? Somali Studies, 1, 6-18. Retrieved from http://somalilibrary.net/wp-content/uploads/magalone/somali-studies-volume-12016/pdf/full.pdf\#page=8.

Mouritsen, P., \& Jaeger, A. (2018). Designing civic education for diverse societies: Models, tradeoffs, and outcomes. Brussels: Migration Policy Institute Europe. https://www.boschstiftung.de/sites/default/files/publications/pdf/2018-11/Civic.EducationDiverse Societies -FINALWEB.pdf

Osler, A., \& Starkey, H. (2006). Education for democratic citizenship: A review of research, policy and practice 1995-2005. Research Papers in Education, 21(4), 433-466. https://doi.org/10.1080/02671520600942438

Powell, B., Ford, R., \& Nowrasteh, A. (2008). Somalia after state collapse: Chaos or improvement? Journal of Economic Behavior \& Organization, 67(3-4), 657-670. https://doi.org/10.1016/j.jebo.2008.04.008

Ross, A. (2007). Citizenship education and identity in Europe. REICE: Revista Electrónica Iberoamericana sobreCalidad, Eficaciay Cambioen Educación, 5(4), 120-131. https://www.academia.edu/19196671/Citizenship_education_and_identity_in_Europe

Rossi, G., Lenzi, M., Sharkey, J. D., Vieno, A., \& Santinello, M. (2016). Factors associated with civic engagement in adolescence: The effects of neighborhood, school, family, and peer contexts. Journal of Community Psychology, 44(8), 1040-1058.

Schulz, W., \& Sibberns, H. (Eds). (2004). The IEA civic education study technical report. Amsterdam: The International Association for the Evaluation of Educational Achievement.

Schulz, W. (2002, April 1-5). Explaining differences in civic knowledge: Multi-level regression analysis of student data from 27 countries. Paper presented at the Annual Meeting of the American Educational Research Association in New Orleans, LA. Retrieved from https://files.eric.ed.gov/fulltext/ED465762.pdf

Schulz, W., Ainley, J., Fraillon, J., Kerr, D., \& Losito, B. (2010). ICCS 2009 international report: Civic knowledge, attitudes and engagement among lower secondary school students in thirty-eight countries. Amsterdam, Netherlands: The International Association for the Evaluation of Educational Achievement (IEA).

Serpell, R., Mumba, P., \& Chansa-Kabali., T. (2011). Early educational foundations for the development of civic responsibility: An african experience. New Directions for Child and Adolescent Development, 134, 77-93. 
Shek, D. T. L., Ma, H. K., \& Sun, R. C. F. (2011). Development of a new curriculum in a positive youth development program: The project p.a.t.h.s in hong kong. The Scientific World Journal, 11(3), 2207-2218. doi:10.1100/2011/289589

Torney-Purta, J., Lehmann, R., Oswald, H., \& Schulz, W. (2001). Citizenship and education in twenty-eight countries: Civic knowledge and engagement at age fourteen. Amsterdam, the Netherlands: International Association for the Evaluation of Educational Achievement (IEA).

Torney-Purta, J., \& Barber, C. (2005). Democratic school engagement and civic participation among european adolescents: Analysis of data from the IEA civic education study. Journal of Social Science Education, 4(3), 13-29. https://d-nb.info/1175045403/34.

Torney-Purta, J., Schwille, J., \& Amadeo, J. (1999). Civic education across countries: Twentyfour national case studies from the IEA civic education project. Amsterdam, the Netherlands: International Association for the Evaluation of Educational Achievement. Retrieved from https://files.eric.ed.gov/fulltext/ED431705.pdf

UNESCO. (1981). Technical education and vocational training: Project findings and recommendations. Report prepared for the Government of the Somalia Democratic Republic by UNESCO. Paris, France: UNDP. Retrieved from https://unesdoc.unesco. org/ark:/48223/pf0000047787.

Van Deth, J. W. (2013). Citizenship and the civic realities of everyday life. In M. Print \& D. Lange (Eds.), Civic Education and Competences for Engaging Citizens in Democracies. Springer (pp 9-21). https://doi.org/10.1007/978-94-6209-172-6_2.

Zaff, J. F., Malanchuk, O., \& Eccles, J. S. (2008). Predicting positive citizenship from adolescence to young adulthood: The effects of a civic context. Applied Development Science, 12(1), 38-53. 